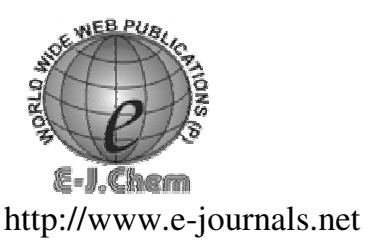

ISSN: 0973-4945; CODEN ECJHAO

E-Journal of Chemistry

Vol. 5, No. 2, pp. 395-403, April 2008

\title{
Transition Metal Complexes of 1, 4(2'-Hydroxyphenyl-1-yl) di-imino azine: Synthesis, Characterization and Antimicrobial Studies
}

\author{
M. REVANASIDDAPPA*, T. SURESH ${ }^{\#}$, SYED KHASIM ${ }^{\$}$, \\ S. C. RAGHAVENDRA ${ }^{\Psi}$, C. BASAVARAJA ${ }^{\S}$ and S. D. ANGADI \\ *Department of Chemistry, ${ }^{\$}$ Department of Physics, ${ }^{\Psi}$ Department of Electronics \& \\ Communication Engineering, PES School of Engineering, Bangalore -560 100 \\ \#Department of Chemistry, Gulbarga University P G Center, Bellary -583 104 \\ ${ }^{\S}$ Department of Chemistry, Inje University, Kimhae - 621749, South Korea \\ Department of Chemistry, Gulbarga University, Gulbarga 585106 \\ revum@rediffmail.com; Phone: : +9845977522
}

Received 2 August 2007; Revised 28 September 2007; Accepted 5 November 2007

\begin{abstract}
The synthesis and characterization of first row transition metal complexes of the 1, 4(2'-hydroxyphenyl-1-yl) di-imino azine $\{1,4(2 ' \mathrm{HPDA})\}$ are reported. The complexes have been characterized by elemental analysis, molar conductance, magnetic studies, IR, 1H NMR and UV-visible studies. They have the stoichiometry of the type $\left[\mathrm{M}\left\{1,4\left(2^{\prime} \mathrm{HPDA}\right)\right\}_{2} 2 \mathrm{H}_{2} \mathrm{O}\right]$ and $\left[\mathrm{M}^{\prime} \mathrm{L}_{2}\right]$ where $\mathrm{M}=$ $\mathrm{Mn}(\mathrm{II}), \mathrm{Fe}(\mathrm{III}), \mathrm{Co}(\mathrm{II}), \mathrm{Ni}(\mathrm{II})$ and $\mathrm{Cu}(\mathrm{II})$, and $\mathrm{M}^{\prime}=\mathrm{ZrO}(\mathrm{II}), \mathrm{VO}(\mathrm{II}), \mathrm{Zn}(\mathrm{II})$, $\mathrm{Cd}(\mathrm{II})$, and $\mathrm{Hg}(\mathrm{II})$. The antibacterial and antifungal activity of the metal complexes has been investigated. Both ligand and complexes have shown good antibacterial and antifungal activity
\end{abstract}

Keywords: 1,4(2'-Hydroxyphenyl-1-yl) di-imino azine $\left\{1,4(2\right.$ 'HPDA) $\}$, IR, ${ }^{1} \mathrm{HNMR}$, Antimicrobial

\section{Introduction}

Metal ions play a vital role in a vast number of biological processes. The ions with biologically active ligands are a subject of considerable interest. Some of the biologically active compounds act via chelation ${ }^{1}$. But for most of them little is known about how metal binding influences their ability. Some heterocyclic azines are known to inhibit marine tumor growth $^{2}$ and acts as fluorescent brightening agents and are photosensitizers ${ }^{3}$. Azines were developed for use an ion selective optical sensors ${ }^{4}$. Mixed azines between opioid antagonist and steroidal ketones ${ }^{5}$ have shown various metal complexes for their antimicrobial and antifungal properties. 
Cisplatin exerts its biological action by preferential binding of the cis- $\left(\mathrm{NH}_{3}\right)_{2} \mathrm{Pt}^{2+}$ unit to the N7 sites of adjacent guanine residues of DNA forming intrastrand cross-links ${ }^{6-7}$. The recent observation that derivatives of 5- and 6-uracilmethylphosphonate (Umpa2-), in combination with Cisplatin, prolong the survival time of mice with lymphoid leukemia ${ }^{8}$, prompted a study of their acid-base properties ${ }^{9}$. It was shown that the stability of these $\mathrm{M}$ (Umpa) complexes ${ }^{10}$ is solely determined by the basicity of the phosphonate group and these two ligands may be considered as simple analogues of uridine 5'-monophosphate (UMP2-). In an effort to combine the antiviral with the anticancer effects, the acid-base and metal ionbinding properties of PMEA (Nucleotide Analogue 9-[2-(Phosphonomethoxy)ethyl]adenine) and of its ternary complexes, (Dien)Pt(PMEA-N1) and (Dien)Pt(PMEA-N7) (Dien = diethylenetriamine), were studied and compared by Kampf G et. $a l^{11}$.

One of the most remarkable results is that the metal nonbinding properties of the phosphonate group are little affected by the nucleobasecoordinated (Dien) $\mathrm{Pt}^{2+}$ units. In this context it is important to understand the effect of metal ions upon their binding to nucleobase residues, i.e. how they affect the acid-base properties of nucleobases. This is crucial with regard to their metal nonbinding, hydrogen-bonding ${ }^{12}$ and stacking properties. In view of the above discussions it has been planned to synthesize $\mathrm{ZrO}$ (II), $\mathrm{VO}$ (II), $\mathrm{Mn}$ (II), $\mathrm{Fe}(\mathrm{III}), \mathrm{Co}(\mathrm{II}), \mathrm{Ni}(\mathrm{II}), \mathrm{Cu}(\mathrm{II}), \mathrm{Zn}(\mathrm{II}), \mathrm{Cd}(\mathrm{II})$ and $\mathrm{Hg}(\mathrm{II})$ complexes of $\left\{1,4\left(2^{\prime} \mathrm{HPDA}\right)\right\}$ to deduce their structure by various techniques such as elemental analysis, molar conductance, UV-Vis, Magnetic susceptibility, IR and ESR data. We have also carried out the antimicrobial activity of the ligand and their metal complexes.

\section{Experimental}

All chemicals used were of analytical grade. The benzophenone hydrazine hydrate was prepared by their literature methods. The metal content was determined as already reported. The nitrogen content was estimated micro-analytically.

\section{Preparation of 1, 4(2 $2^{I}$-hydroxyphenyl-1-yl) di-imino azine $\left\{1,4\left(2^{\prime} H P D A\right)\right\}$}

Benzophenone is condensed with hydrazine hydrate in presence of catalytic amount of concentrated hydrochloric acid. The resulting product was treated with aromatic aldehyde in the molar ratio of 1: 2 . The reaction mixture was refluxed on water bath for about $4 \mathrm{~h}$. The solid azine separated after a few minutes. The product was filtered out and washed successively with alcohol. The compound was re-crystallized from alcohol and dried in vacuum over fused $\mathrm{CaCl}_{2}$ [Mol. Formula $\mathrm{C}_{14} \mathrm{H}_{12} \mathrm{~N}_{2} \mathrm{O}$ M.P. $=187^{\circ} \mathrm{C}$, yield $=75 \%$ ].

\section{Preparation of complexes}

Metal complexes were prepared by adding $(0.2$ mole, $20 \mathrm{~mL})$ aqueous metal(II) chlorides to 0.1 mole in $50 \mathrm{~mL}$ alcohol. The complexes did not separate immediately, the reaction was refluxed on water bath for about $2 \mathrm{~h}$, during which complexes start separating out. The solution was concentrated and cooled to room temperature. The crystalline light colored complexes were filtered out, washed with water and alcohol to remove the unreacted salts and ligand. In the case of $\mathrm{VO}(\mathrm{II})$ and $\mathrm{ZrO}$ (II) metal oxy chlorides were used. All the complexes were dried in open air and kept in vacuum desiccator.

\section{Physical measurements}

The magnetic susceptibility of the complexes was made on Gouy balance using $\mathrm{Hg}\left[\mathrm{Co}(\mathrm{NCS})_{4}\right]$ as the calibrant at room temperature. The IR spectra were obtained from Perkin-Elmer (model 783) in KBr pellets. The electronics spectra of $\mathrm{VO}(\mathrm{II}), \mathrm{Mn}(\mathrm{II}), \mathrm{Fe}(\mathrm{III})$, 
$\mathrm{Co}(\mathrm{II}), \mathrm{Ni}(\mathrm{II})$, and $\mathrm{Cu}(\mathrm{II})$ complexes were recorded on Elico CL-24 spectrophotometer in DMF $\left(10^{-3} \mathrm{M}\right)$ solution. The conductance measurements were made on Elico CM-82T conductivity bridge in DMF $\left(10^{-3} \mathrm{M}\right)$ solution. All the complexes gave satisfactory analysis for metal and nitrogen content. The Electron spin resonance spectra of Copper(II), complex in poly crystalline state were recorded on Varian X - band ESR spectrometer diphenyl picryl hydrazine (DPPH) free radical of " $g$ " marker $(\mathrm{g}=2.0027)$ at room temperature.

\section{Results and Discussion}

Analytical data for the complexes indicate 1:2 stoichiometries for all the complexes (Table 1). All complexes possess high melting points and are stable in air and partially or insoluble in common organic solvents and soluble in DMF, DMSO and pyridine. The molar conductance of the complexes are in the range 8.19- $25.00 \mathrm{ohm}^{-1} \mathrm{~cm}^{2}$ mole ${ }^{-1}$ in DMF $\left(10^{-3} \mathrm{M}\right)$ solution. These values are too low to account for any electrolytic behavior of the complexes.

\section{Magnetic and Electronic spectral studies}

Electronic spectral studies of $\mathrm{VO}(\mathrm{II}), \mathrm{Mn}(\mathrm{II}), \mathrm{Fe}(\mathrm{III}), \mathrm{Co}(\mathrm{II}), \mathrm{Ni}$ (II) and $\mathrm{Cu}(\mathrm{II})$ complexes were carried out in DMSO solution $\left(1 \times 10^{-3} \mathrm{M}\right)$. The electronic spectrum of oxovanadium (IV) complex exhibited three bands ${ }^{12}$ in the region $22000-13000 \mathrm{~cm}^{-1}$. The present oxovanadium complex of the ligand $\{1,4(2$ HPDA $)\}$, have displayed three bands in the region $12820.51-23809.52 \mathrm{~cm}^{-1}$. Bajgur et al. ${ }^{13}$, have reported three absorption bands in the region $13000-13650 \mathrm{~cm}^{-1}, 16300-16800 \mathrm{~cm}^{-1}$ and $21000-22000 \mathrm{~cm}^{-1}$ for vanadium complexes derived from carbohydrazones. In view of these facts and on the basis of available reports the vanadium complex under the present study has been assigned the square pyramidal geometry. Sakurai et $a l^{14}$, have reported the magnetic susceptibility values in the range of 1.7 to 1.8 for the complexes, confirming that they all in the mononuclear vanadyl state. In the present investigation, the magnetic moment value observed for $\mathrm{VO}$ (II) complex of the ligand $\{1,4(2 ' \mathrm{HPDA})\}$ is $1.6 \mathrm{BM}$. This value is agreeable with the spin only value for oxovanadium(II) complex, indicates that square pyramidal geometry around the $\mathrm{VO}$ (II) ion.

Magnetic studies show that the ground term of the manganese(II) ion is the sextet. The only sextet term of the $d^{5}$ configuration in octahedral stereochemistry is the ${ }^{6} \mathrm{~A}_{1 \mathrm{~g}}$. The transitions of the spectrum are assigned as from the ${ }^{6} \mathrm{~A}_{1 \mathrm{~g}}$ ground term to the quartet excited terms $^{15}$. The electronic spectrum of the $\mathrm{Mn}(\mathrm{II})$ complex of ligand $\left\{1,4\left(2^{\prime} \mathrm{HPDA}\right)\right\}$ indicated by the bands in the region 15151.51-16666.66 $\mathrm{cm}^{-1}$ due to ${ }^{6} \mathrm{~A}_{1 \mathrm{~g}} \rightarrow{ }^{4} \mathrm{~T}_{1 \mathrm{~g}}\left({ }^{4} \mathrm{G}\right)\left(v_{1}\right),{ }^{6} \mathrm{~A}_{1 \mathrm{~g}} \rightarrow{ }^{4} \mathrm{E}_{\mathrm{g}}$ $\left({ }^{4} \mathrm{G}\right)\left(\mathrm{v}_{2}\right),{ }^{6} \mathrm{~A}_{1 \mathrm{~g}} \rightarrow{ }^{4} \mathrm{~T}_{2 \mathrm{~g}}\left({ }^{4} \mathrm{D}\right)\left(\mathrm{v}_{3}\right),{ }^{6} \mathrm{~A}_{1 \mathrm{~g}} \rightarrow{ }^{4} \mathrm{~T}_{1 \mathrm{~g}}\left({ }^{4} \mathrm{P}\right)\left(\mathrm{v}_{4}\right)$ transitions respectively, indicating octahedral geometry ${ }^{16}$ for these complexes. In the present investigation the observed magnetic moment values for $\mathrm{Mn}(\mathrm{II})$ complex of ligand $\left\{1,4\left(2^{\prime} \mathrm{HPDA}\right)\right\}$ is $5.25 \mathrm{BM}$, which is well within the range expected for octahedral geometry around the central metal ion ${ }^{17}$.

The absorption spectra of high-spin iron(III) complexes have been measured with difficulty ${ }^{18}$. The ground state of high spin octahedrally coordinated Fe (III) complexes is ${ }^{6} \mathrm{~A}_{1 \mathrm{~g}}$. The four lowest energy bands are due to the transition from ${ }^{6} \mathrm{~A}_{1 \mathrm{~g}}$ to ${ }^{4} \mathrm{~T}_{\mathrm{gg}},{ }^{4} \mathrm{~T}_{2 \mathrm{~g}},{ }^{4} \mathrm{E}_{\mathrm{g}}$, and ${ }^{4} \mathrm{~A}_{1 \mathrm{~g}}$, excited states. A very sharp band near $25000 \mathrm{~cm}^{-1}$ is due to the transitions to the accidentally degenerate ${ }^{4} \mathrm{~A}_{1 \mathrm{~g}}$ and ${ }^{4} \mathrm{E}_{\mathrm{g}}$ levels. These bands possibly arise from an admixture of spin quartet character to the ground state through spin-orbital coupling. The transitions ${ }^{6} \mathrm{~A}_{1 \mathrm{~g}} \rightarrow{ }^{4} \mathrm{~A}_{1 \mathrm{~g}},{ }^{4} \mathrm{E}_{\mathrm{g}}(\mathrm{G})$ and ${ }^{4} \mathrm{E}_{\mathrm{g}}(\mathrm{D})$ are of interest since their energies are independent of the magnitude of $\mathrm{D}_{\mathrm{q}}$ and this permits a comparison of the free ion and bound ion term separations. In the present investigation, the $\mathrm{Fe}$ (III) complex of ligand $\{1,4(2$ HPDA $)\}$ have shown three bands in the region $13513.51-20833.33 \mathrm{~cm}^{-1}$ which are characteristic of octahedral geometry. The observed magnetic moment value for Fe(III) complex in the present investigation is 5.67 B.M which is a characteristic of octahedral geometry ${ }^{19}$. 
Table 1. Elemental analysis, Color, Melting point and Conductance data for $\left\{1,4\left(2^{\prime} \mathrm{HPDA}\right)\right\}$ and Metal complexes

\begin{tabular}{|c|c|c|c|c|c|c|c|c|c|}
\hline \multirow{2}{*}{$\begin{array}{l}\text { S. } \\
\text { No }\end{array}$} & \multirow[t]{2}{*}{ Ligand/complexes } & \multicolumn{4}{|c|}{$\begin{array}{c}\text { Analysis\% } \\
\text { Found (Calculated) }\end{array}$} & \multirow[t]{2}{*}{ M.P } & \multirow[t]{2}{*}{ Color } & \multirow{2}{*}{$\begin{array}{l}\text { Magnetic } \\
\text { moment } \\
\text { BM }\end{array}$} & \multirow{2}{*}{$\begin{array}{c}\text { Molar } \\
\text { Conductance } \\
\Omega^{-1} \mathrm{Cm}^{2} \mathrm{Mol}^{-1}\end{array}$} \\
\hline & & $\mathrm{C}$ & $\mathrm{H}$ & $\mathrm{N}$ & $\mathrm{M}$ & & & & \\
\hline 01 & $\{1,4(2 ' H P D A)\}$ & $\begin{array}{c}75.25 \\
(75.00)\end{array}$ & $\begin{array}{c}5.48 \\
(5.38)\end{array}$ & $\begin{array}{l}12.75 \\
(12.50)\end{array}$ & - & $187^{\circ} \mathrm{C}$ & Yellow & - & - \\
\hline 02 & $\mathrm{ZrO}[\{1,4(2 ' \mathrm{HPDA})\}]_{2}$ & $\begin{array}{c}59.04 \\
(60.29)\end{array}$ & $\begin{array}{c}4.05 \\
(3.99)\end{array}$ & $\begin{array}{l}11.51 \\
(10.04)\end{array}$ & $\begin{array}{l}17.12 \\
(16.37)\end{array}$ & $>300^{\circ} \mathrm{C}$ & Yellow & - & 25 \\
\hline 03 & $\mathrm{VO}[\{1,4(2 ' \mathrm{HPDA})\}]_{2}$ & $\begin{array}{c}66.00 \\
(65.50)\end{array}$ & $\begin{array}{c}4.56 \\
(4.28)\end{array}$ & $\begin{array}{l}10.32 \\
(10.99)\end{array}$ & $\begin{array}{l}10.20 \\
(9.99)\end{array}$ & $>300^{\circ} \mathrm{C}$ & $\begin{array}{l}\text { Yellow } \\
\text { Green }\end{array}$ & 1.68 & 45 \\
\hline 04 & $\mathrm{Mn}\left[\left\{1,4\left(2{ }^{\prime} \mathrm{HPDA}\right)\right\}\right]_{2} .2 \mathrm{H}_{2} \mathrm{O}$ & $\begin{array}{c}61.21 \\
(62.57)\end{array}$ & $\begin{array}{c}5.27 \\
(4.87)\end{array}$ & $\begin{array}{l}11.06 \\
(10.42)\end{array}$ & $\begin{array}{l}11.46 \\
(10.23)\end{array}$ & $>300^{\circ} \mathrm{C}$ & Brown & 5.25 & 31 \\
\hline 05 & $\mathrm{Fe}\left[\left\{1,4\left(2{ }^{\prime} \mathrm{HPDA}\right)\right\}\right]_{2} .2 \mathrm{H}_{2} \mathrm{O}$ & $\begin{array}{c}61.70 \\
(62.47)\end{array}$ & $\begin{array}{c}4.89 \\
(4.83)\end{array}$ & $\begin{array}{l}10.69 \\
(10.41)\end{array}$ & $\begin{array}{l}11.96 \\
(10.38)\end{array}$ & $>300^{\circ} \mathrm{C}$ & $\begin{array}{l}\text { Reddish } \\
\text { Brown }\end{array}$ & 5.67 & 32 \\
\hline 06 & $\mathrm{Co}[\{1,4(2 ' \mathrm{HPDA})\}]_{2} .2 \mathrm{H}_{2} \mathrm{O}$ & $\begin{array}{c}58.85 \\
(62.11)\end{array}$ & $\begin{array}{c}5.03 \\
(4.80)\end{array}$ & $\begin{array}{l}10.60 \\
(10.35)\end{array}$ & $\begin{array}{l}11.28 \\
(10.89)\end{array}$ & $>300^{\circ} \mathrm{C}$ & Orange & 4.65 & 09.23 \\
\hline 07 & $\mathrm{Ni}[\{1,4(2 ' \mathrm{HPDA})\}]_{2} \cdot 2 \mathrm{H}_{2} \mathrm{O}$ & $\begin{array}{l}59.76 \\
(62.14)\end{array}$ & $\begin{array}{c}5.30 \\
(4.80)\end{array}$ & $\begin{array}{c}9.60 \\
(10.35)\end{array}$ & $\begin{array}{c}11.96 \\
(10.89)\end{array}$ & $>300^{\circ} \mathrm{C}$ & $\begin{array}{l}\text { Yellow } \\
\text { Green }\end{array}$ & 3.23 & 21.22 \\
\hline 08 & $\mathrm{Cu}[\{1,4(2 ' \mathrm{HPDA})\}]_{2} \cdot 2 \mathrm{H}_{2} \mathrm{O}$ & $\begin{array}{c}60.34 \\
(61.50)\end{array}$ & $\begin{array}{c}5.28 \\
(4.76)\end{array}$ & $\begin{array}{c}10.92 \\
(10.26)\end{array}$ & $\begin{array}{l}10.20 \\
(11.64)\end{array}$ & $>300^{\circ} \mathrm{C}$ & Brown & 1.86 & 8.301 \\
\hline 09 & $\mathrm{Zn}[\{1,4(2 \text { 'HPDA })\}]_{2}$ & $\begin{array}{c}65.12 \\
(65.62)\end{array}$ & $\begin{array}{c}4.34 \\
(5.07)\end{array}$ & $\begin{array}{c}11.28 \\
(10.93)\end{array}$ & $\begin{array}{l}13.03 \\
(12.88)\end{array}$ & $>300^{\circ} \mathrm{C}$ & Orange & - & 30 \\
\hline 10 & $\mathrm{Cd}[\{1,4(2 \text { 'HPDA })\}]_{2}$ & $\begin{array}{c}60.05 \\
(60.17)\end{array}$ & $\begin{array}{c}4.50 \\
(3.93)\end{array}$ & $\begin{array}{l}10.11 \\
(10.02)\end{array}$ & $\begin{array}{l}21.08 \\
(20.03)\end{array}$ & $>300^{\circ} \mathrm{C}$ & Yellow & - & 22 \\
\hline 11 & $\operatorname{Hg}[\{1,4(2 ' H P D A)\}]_{2}$ & $\begin{array}{c}51.62 \\
(51.99) \\
\end{array}$ & $\begin{array}{c}3.66 \\
(3.40)\end{array}$ & $\begin{array}{r}8.89 \\
(8.66) \\
\end{array}$ & $\begin{array}{l}31.32 \\
(31.04) \\
\end{array}$ & $>300^{\circ} \mathrm{C}$ & Brown & - & 23 \\
\hline
\end{tabular}


The electronic spectra of Co(II) complex of ligand $\{1,4(2 ' H P D A)\}$ exhibited bands in the region 10101.01, 18181.81 and $23923.44 \mathrm{~cm}^{-1}$ due to the ${ }^{4} \mathrm{~T}_{1 \mathrm{~g}}(\mathrm{~F}) \rightarrow{ }^{4} \mathrm{~T}_{2 \mathrm{~g}}(\mathrm{~F})\left(\mathrm{v}_{1}\right),{ }^{4} \mathrm{~T}_{1 \mathrm{~g}}(\mathrm{~F}) \rightarrow{ }^{4} \mathrm{~A}_{2 \mathrm{~g}}$ $(\mathrm{F})\left(\mathrm{v}_{2}\right)$ and ${ }^{4} \mathrm{~T}_{1 \mathrm{~g}}(\mathrm{~F}) \rightarrow{ }^{4} \mathrm{~T}_{1 \mathrm{~g}}(\mathrm{P})\left(\mathrm{v}_{3}\right)$ transitions respectively. These transitions suggest octahedral geometry for the $\mathrm{Co}$ (II) complexes. These assignments are in good agreement with the reported values $^{20,21}$. The observed magnetic moment value for Co(II) complexes of $\left\{1,4\left(2^{\prime}\right.\right.$ HPDA) $\}$ is 4.65 $\mathrm{BM}$, which indicates clearly the octahedral geometry of the Co(II) complex ${ }^{22}$.

Electronic spectra of $\mathrm{Ni}(\mathrm{II})$ complex of the ligand $\left\{1,4\left(2{ }^{\prime} \mathrm{HPDA}\right)\right\}$ in the present investigation exhibited three bands in the region $11135.83-11428.57 \mathrm{~cm}^{-1}$, in DMSO solution. These bands are assigned due to ${ }^{3} \mathrm{~A}_{2 \mathrm{~g}}(\mathrm{~F}) \rightarrow{ }^{3} \mathrm{~T}_{2 \mathrm{~g}}(\mathrm{~F})\left(\mathrm{v}_{1}\right),{ }^{3} \mathrm{~A}_{2 \mathrm{~g}}(\mathrm{~F}) \rightarrow{ }^{3} \mathrm{~T}_{1 \mathrm{~g}}(\mathrm{~F})\left(\mathrm{v}_{2}\right)$ and ${ }^{3} \mathrm{~A}_{2 \mathrm{~g}}(\mathrm{~F}) \rightarrow{ }^{3} \mathrm{~T}_{1 \mathrm{~g}}(\mathrm{P})\left(\mathrm{v}_{3}\right)$ transitions respectively. Moreover, the ratio $v_{2} / v_{1}$ is in the range $1.21-1.38$ is indicative of octahedral stereochemistry for these $\mathrm{Ni}(\mathrm{II})$ complexes. Koji et al., ${ }^{23}$ have reported a band around $\sim 950 \mathrm{~nm}$ for $\mathrm{d}-\mathrm{d}$ component of the $\mathrm{Ni}$ (II) complex. In the present study, electronic spectral band in the region $11135.83-11428.57$ $\mathrm{cm}^{-1}(\sim 900 \mathrm{~nm})$ is attributable to a d-d component of the Ni(II) complexes ${ }^{23}$. The magnetic moment values for $\mathrm{Ni}(\mathrm{II})$ complexes of ligands $\left\{1,4\left(2^{\prime} \mathrm{HPDA}\right)\right\}$ is $3.23 \mathrm{BM}$, which is well within the range expected for octahedral geometry around the central metal ion ${ }^{24}$.

$\mathrm{Cu}(\mathrm{II})$ complex of the ligand $\{1,4(2$ HPDA $)\}$, showed broad band at $16129.00 \mathrm{~cm}^{-1}$. Campbell and Grzeskowiak ${ }^{25}$ have suggested that tetrahedrally distorted octahedral geometry for $\mathrm{Cu}$ (II) complexes derived from thiosemicarbazide ligands. The observed broad band in the present $\mathrm{Cu}(\mathrm{II})$ complex of ligand $\left\{1,4\left(2^{\prime} \mathrm{HPDA}\right)\right\}$ can be assigned to the envelope of ${ }^{2} \mathrm{~B}_{1 \mathrm{~g}} \rightarrow{ }^{2} \mathrm{E}_{\mathrm{g}}$, and ${ }^{2} \mathrm{~B}_{1 \mathrm{~g}} \rightarrow{ }^{2} \mathrm{E}_{2 \mathrm{~g}}$ transitions in distorted octahedral geometry of $\mathrm{Cu}$ (II). The observed magnetic moment value for $\mathrm{Cu}$ (II) Complex 1.86 BM. This value is agreeable to spin only value. Hence observed magnetic moment for the $\mathrm{Cu}$ (II) complexes under study that indicates it has distorted octahedral ${ }^{26}$ configurations.

\section{IR Spectra}

The chemical structures of the symmetric and asymmetric dimmers are similar to benzylic dimmers. Except for the hydroxyl groups, the hydroxyl stretching regions of FT-IR spectra for the symmetric and asymmetric dimmers will reflect the distribution of hydrogen bonding in the dimmers. In the study of hydrogen bonding for a benzoxazine model dimmer using methyl ammine by Dunkers ${ }^{27}$, it was shown that it is possible to form several kinds of hydrogen bonded species, such as $-\mathrm{OH} \ldots . \mathrm{O}$ inter molecular hydrogen bonding, $-\mathrm{OH} \ldots . \mathrm{O}$ intra molecular hydrogen bonding and $-\mathrm{H} \ldots \mathrm{N}$ intramolecular hydrogen bonding. The bond centered at $3400 \mathrm{~cm}^{-1}$ shows the existence of $-\mathrm{OH}$.... O intermolecular hydrogen bonding, and the broad band between $2500 \mathrm{~cm}^{-1}$ and $3300 \mathrm{~cm}^{-1}$ might be designated for $-\mathrm{OH} \ldots . \mathrm{O}$ intra molecular hydrogen bonding and $-\mathrm{OH} \ldots . \mathrm{N}$ intramolecular hydrogen bonding. It is well established that the Schiff bases having o-hydroxy group either on aldehyde or aniline residue can form intramolecular hydrogen bonding with azomethine nitrogen ${ }^{28}$. This has direct impact on the $v_{\mathrm{OH}}$ vibrations and the band due to $v_{\mathrm{OH}}$ shifts to the lower frequency with broadening of the band and decrease in the intensity. The extent of shift depends on the strength of hydrogen bonding ${ }^{29}$. The stronger the hydrogen bonding, the greater is the shift towards the lower frequency side and this is followed by an immense change in the intensity of the band. In our earlier reports ${ }^{30}$ we have observed hydrogen bonded -OH with nitrogen atom of azomethine group appeared in the region $2875-2746 \mathrm{~cm}^{-1}$.

In addition to these bands in the ligand $\{1,4(2$ HPDA $)\}$, a high intensity band observed in the range $1265 \mathrm{~cm}^{-1}$ is due to the phenolic $v_{\mathrm{C}-\mathrm{O}}$ vibrations ${ }^{31}$. In phenols, both $-\mathrm{OH}$ bending and phenolic $\mathrm{v}_{\mathrm{C}-\mathrm{O}}$ vibrations are coupled and they give rise to absorption at 1340 and $1175 \mathrm{~cm}^{-1}$ for free $-\mathrm{OH}$ and at $1230 \mathrm{~cm}^{-1}$ for bending - $\mathrm{OH}$. Teyssinc and Charette ${ }^{32}$ have assigned a band at 
$1280 \mathrm{~cm}^{-1}$ to the $-\mathrm{OH}$ bending vibrations and other at $1324 \mathrm{~cm}^{-1}$ to the $\mathrm{v}_{\mathrm{C}-\mathrm{O}}$ vibrations in the acetyl acetone Schiff bases. Assignment in the ligand has been made by comparing the spectra with those of a model compound viz., benzylidene aniline and salicylidene aniline. In the present investigation the band due to hydrogen bonded -OH group was observed at $3040 \mathrm{~cm}^{-1}$ in the case of $\{1,4(2$ HPDA $)\}$ ligand. The medium bands observed in the region $1619-1575 \mathrm{~cm}^{-1}$ are assigned to $\mathrm{v}_{\mathrm{C}=\mathrm{N}}$ group ${ }^{33}$. In the present study of the $\mathrm{ZrO}(\mathrm{II}), \mathrm{VO}(\mathrm{II}), \mathrm{Mn}(\mathrm{II}), \mathrm{Fe}(\mathrm{III}), \mathrm{Co}(\mathrm{II})$, $\mathrm{Ni}(\mathrm{II})$ and $\mathrm{Cu}(\mathrm{II})$, complexes of ligand $\{1,4(2$ HPDA $)\}$, indicates the presence of weak band around $847-803 \mathrm{~cm}-1$, which may be assigned due to the presence of coordinated water molecule in the complexes. Whereas in case of $\mathrm{Zn}(\mathrm{II}), \mathrm{Cd}(\mathrm{II})$, and $\mathrm{Hg}(\mathrm{II})$ complexes of ligand $\{1,4(2$ 'HPDA $)\}$, absence of coordinated water molecule.

The assignment of the band to various $v_{\mathrm{M}-\mathrm{O}}$ and $v_{\mathrm{M}-\mathrm{N}}$ vibrations in the lower frequency region appears to be complicated as the ligand vibrations interfere in this region. The low frequency skeletal vibrations due to $\mathrm{M}-\mathrm{O}$ and $\mathrm{M}-\mathrm{N}$ stretching provide direct evidence for the complexation. This is because a large dipole moment change is involved in the vibration of $\mathrm{M}$ $\mathrm{O}$ bond in comparison to that of $\mathrm{M}-\mathrm{N}$ bond ${ }^{34}$. Choudhary et al. ${ }^{35}$ have reported bands in the region $600-450 \mathrm{~cm}^{-1}$ for $\mathrm{M}-\mathrm{O}$ and $400-310 \mathrm{~cm}^{-1}$ for M-N vibrations respectively. Bipin et al., ${ }^{36}$ have also reported that the vibrations in the region $565-552 \mathrm{~cm}^{-1}$ and the bands around $414 \mathrm{~cm}^{-}$ ${ }^{1}$ for M-N and M-N respectively. Present study of the complexes $v_{M-N}$ vibration occur in the region $540-490 \mathrm{~cm}^{-1}$ and $v_{\mathrm{M}-\mathrm{O}}$ occur in the region $450-400 \mathrm{~cm}^{-1}$ have been assigned.

\section{ESR Spectra}

In order to obtain more information about the magnetic environment of the $\mathrm{Cu}(\mathrm{II})$ complexes, powder samples were used to record X-band ESR spectra of the complexes at room temperature. ESR spectra of the polycrystalline $\mathrm{Cu}$ (II) complex ' $\mathrm{g}$ ' values obtained from the spectra are presented in Table-2. In the present case, copper (II) complexes, measured in polycrystalline sample at room temperature, give the following values: $\mathrm{g}_{\|}=2.06, \mathrm{~g} \perp=2.13$ for the $\left[\mathrm{Cu}\{1,4(2 \mathrm{HPDA})\}_{2} 2 \mathrm{H}_{2} \mathrm{O}\right]$ and $\mathrm{g}_{\|}=2.03, \mathrm{~g}_{\perp}=2.10$. The trend, $\mathrm{g}_{\|}<\mathrm{g}_{\perp}$ showed that the electron is delocalized in $\mathrm{d}_{\mathrm{z}}^{2}$ orbital of the ground state of $\mathrm{Cu}(\mathrm{II})$ and the spectra are characteristic of axial (compressed octahedral) symmetry. The parameter $\mathrm{G}$, determined as $\mathrm{G}=\left(\mathrm{g}_{\|}-2\right) /(\mathrm{g} \perp-2)$ is found to be much less than 4 suggesting considerable interaction in the solid state ${ }^{37}$.

Table 2. Electron spin resonance spectral data

\begin{tabular}{ccccccc}
\hline S.No & Complex & $\mathrm{g}_{\|}$ & $\mathrm{g}_{\perp}$ & $\mathrm{g}_{\mathrm{e}}$ & $\mathrm{G}_{\mathrm{av}}$ & $\mathrm{G}$ \\
\hline 1 & $\mathrm{Cu}\left\{1,4\left(2^{\prime} \mathrm{HPDA}\right)\right\}_{2} 2 \mathrm{H}_{2} \mathrm{O}$ & 2.06 & 2.16 & 2.0039 & 2.11 & 3.75 \\
\hline${ }^{l} \mathrm{H} N M R$ & Spectrum of the ligand $\left\{1,4\left(2^{\prime} \mathrm{HPDA}\right)\right\}$ & & & &
\end{tabular}

The ${ }^{1} \mathrm{H}$ NMR spectrum of ligand 1-Phenyl-4-(2 -hydroxyphenyl-1-yl) Di-imino azine ( $\{1$, $4(2$ 'HPDA) $)$ ) showed a peak at $\delta 2.35(\mathrm{~s}, 3 \mathrm{H})$ due to $-\mathrm{CH}_{3}$ group on the phenol ring. Two azomethine protons have resonated as a singlet at $\delta 8.73(\mathrm{~s}, 2 \mathrm{H})$.Proton due to phenolic $\mathrm{OH}$ has appeared at $\delta 12.29(\mathrm{~s}, 1 \mathrm{H})$ as a singlet whereas the eight aromatic protons have resonated in the region $\delta 7.51-8.30(\mathrm{~m}, 8 \mathrm{H})$ as a multiplet.

${ }^{1} H$ NMR spectra of Cd (II) complex of $\left\{1,4\left(2^{\prime} H P D A\right)\right\}$

${ }^{1} \mathrm{HNMR}$ spectrum of Cd (II) complex of ligand $\{1,4(2$ 'HPDA) $\}$ and the sample was scanned in DMSO- $d_{6}$ showed a peak at $\delta 2.2\left(\mathrm{~s}, 6,2 \mathrm{xArCH}_{3}\right)$ due to six methyl protons at 4-position of phenyl ring. Four methylene protons have resonated at $\delta 3.6\left(\mathrm{~s}, 4,2 \mathrm{xCH}_{2}\right)$ and four aromatic protons of the phenyl ring have resonated as a singlet at $\delta 7.5\left(\mathrm{~s}, 4,2 \times \mathrm{ArH}_{2}\right)$ respectively. Four azomethine protons have appeared at $\delta 8.4(\mathrm{~s}, 4,-\mathrm{CH}=\mathrm{N}-)$ as a singlet. The 
proton of phenolic $\mathrm{OH}$ group which was observed at $\delta 12.0$ in case of ligand has disappeared in complex, indicating coordination of the phenoxide ion to the metal ions via deprotonation.

\section{Antibacterial Activity}

The comparison of inhibition zone values for the metal complexes are given in Table 3 and Table 4, reveals that the antimicrobial activity could be mainly due to the structure of the complexes and also the oxidation state of the metal ions. These results must be directly related to the greater biological activity exhibited by the tetrahedral $\mathrm{Zn}(\mathrm{II}), \mathrm{Cd}$ (II) and $\mathrm{Hg}$ (II) complexes compared to the squre pyramidal $\mathrm{ZrO}$ (II) and $\mathrm{VO}$ (II) and octahedral $\mathrm{Mn}$ (II), $\mathrm{Fe}(\mathrm{III}), \mathrm{Co}(\mathrm{II}), \mathrm{Ni}(\mathrm{II})$ and $\mathrm{Cu}(\mathrm{II})$ complexes.

Table 3. Antibacterial activities of $\{1,4(2$ 'HPDA $)\}$ and their metal complexes

\begin{tabular}{|c|c|c|c|}
\hline $\begin{array}{l}\text { S. } \\
\text { No. }\end{array}$ & Sample Name & $\begin{array}{c}\text { Klebsiella } \\
\mathrm{mm}\end{array}$ & $\begin{array}{c}\text { Pseudomonas } \\
\mathrm{mm}\end{array}$ \\
\hline & $\{1,4(2 ' H P D A)\}$ Ligand $)$ & - & - \\
\hline 1 & $\mathrm{Mn}[\{1,4(2 \mathrm{HPDA})\}]_{2} 2 \mathrm{H}_{2} \mathrm{O}$ & - & - \\
\hline 2 & $\mathrm{Co}[\{1,4(2 \text { HPDA })\}]_{2} 2 \mathrm{H}_{2} \mathrm{O}$ & 17.00 & 12.5 \\
\hline 3 & $\mathrm{Ni}[\{1,4(2 ' \mathrm{HPDA})\}]_{2} 2 \mathrm{H}_{2} \mathrm{O}$ & 06.25 & 11.5 \\
\hline 4 & $\mathrm{Cu}[\{1,4(2 \text { HPDA })\}]_{2} 2 \mathrm{H}_{2} \mathrm{O}$ & 13.25 & 14.66 \\
\hline 5 & $\mathrm{Fe}\left[\left\{1,4\left(2^{\prime} \mathrm{HPDA}\right)\right\}\right]_{2} 2 \mathrm{H}_{2} \mathrm{O}$ & 14.33 & 08.00 \\
\hline 6 & $\mathrm{ZrO}[\{1,4(2 ' \mathrm{HPDA})\}]_{2}$ & 14.66 & 14.66 \\
\hline 7 & $\mathrm{VO}\left[\left\{1,4\left(2^{\prime} \mathrm{HPDA}\right)\right\}\right]_{2}$ & 12.66 & 11.33 \\
\hline 8 & $\mathrm{Zn}\left[\left\{1,4\left(2^{\prime} \mathrm{HPDA}\right)\right\}\right]_{2}$ & 12.66 & 17.33 \\
\hline 9 & $\mathrm{Cd}[\{1,4(2 ' \mathrm{HPDA})\}]_{2}$ & 18.33 & 15.66 \\
\hline \multirow[t]{2}{*}{10} & $\operatorname{Hg}\left[\left\{1,4\left(2^{\prime} \mathrm{HPDA}\right)\right\}\right]_{2}$ & 18.00 & 22.33 \\
\hline & Standards Gentamicin & 19.00 & 17.35 \\
\hline
\end{tabular}

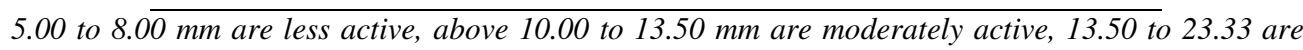
significantly active.

Table 4. Antifungal Activities of various synthesized metal $\{1,4(2$ HPDA $)\}$ complexes:

\begin{tabular}{clcc}
\hline $\begin{array}{r}\text { S1 } \\
\text { No. }\end{array}$ & Name of the complexes & $\begin{array}{c}\text { A.Niger } \\
\mathrm{mm}\end{array}$ & $\begin{array}{c}\text { A.Flavous } \\
\mathrm{mm}\end{array}$ \\
\hline & $\left\{1,4\left(2^{\prime} \mathrm{HPDA}\right)\right\}$ & 11.00 & 05.00 \\
1. & $\mathrm{Mn}\left[\left\{1,4\left(2^{\prime} \mathrm{HPDA}\right)\right\}\right]_{2} 2 \mathrm{H}_{2} \mathrm{O}$ & 12.66 & 07.00 \\
2. & $\mathrm{Co}\left[\left\{1,4\left(2^{\prime} \mathrm{HPDA}\right)\right\}\right]_{2} 2 \mathrm{H}_{2} \mathrm{O}$ & 16.44 & 05.66 \\
4. & $\mathrm{Ni}\left[\left\{1,4\left(2^{\prime} \mathrm{HPDA}\right)\right\}\right]_{2} 2 \mathrm{H}_{2} \mathrm{O}$ & 10.66 & 07.00 \\
4. & $\mathrm{Cu}\left[\left\{1,4\left(2^{\prime} \mathrm{HPDA}\right)\right\}\right]_{2} 2 \mathrm{H}_{2} \mathrm{O}$ & 09.66 & 07.66 \\
5. & $\mathrm{Fe}\left[\left\{1,4\left(2^{\prime} \mathrm{HPDA}\right)\right\}\right]_{2} 2 \mathrm{H}_{2} \mathrm{O}$ & 14.44 & 06.00 \\
6. & $\mathrm{ZrO}\left[\left\{1,4\left(2^{\prime} \mathrm{HPDA}\right)\right\}\right]_{2}$ & 11.44 & 05.44 \\
7. & $\mathrm{VO}[\{1,4(2 \text { 'HPDA })\}]_{2}$ & 14.66 & 07.00 \\
8. & $\mathrm{Zn}\left[\left\{1,4\left(2^{\prime} \mathrm{HPDA}\right)\right\}\right]_{2}$ & 11.66 & 05.00 \\
9 & $\mathrm{Cd}\left[\left\{1,4\left(2^{\prime} \mathrm{HPDA}\right)\right\}\right]_{2}$ & 12.66 & 06.00 \\
10. & $\mathrm{Hg}[\{1,4(2 ' \mathrm{HPDA})\}]_{2}$ & 29.44 & 21.66 \\
& $\mathrm{Standard} \mathrm{Nistatin}$ & 20.11 & 21.33
\end{tabular}

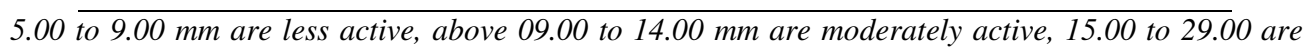
significantly active 
A possible explanation for the high toxicity of metal complexes can be explained as follows. The increase in the activity of metal complexes may be due to effect of metal ions on the normal cell process. The polarity of metal ion is considerably reduced on chelation which is mainly because of partial sharing of its positive charge with a donor groups and possibly $\pi$-electron delocalization over the whole molecule. Such molecule increases the liphophilic character of the metal complexes which probably leads to break down of permeability barrier of the cells resulting in interference with normal cell process ${ }^{38}$. Better activities of the metal complexes as compared to free ligand could also be understood in terms of chelation theory, which explains that a decrease in polarizability of the metal could enhance the liphophilicity of the complexes.

\section{Conclusions}

Based on the above observations of IR, ESR, electronic spectral data, magnetic, conductance measurements and insolubility in common organic solvents and high melting points, we propose the octahedral structure to $\mathrm{Mn}(\mathrm{II}), \mathrm{Fe}(\mathrm{III}), \mathrm{Co}(\mathrm{II}), \mathrm{Ni}(\mathrm{II})$ and $\mathrm{Cu}(\mathrm{II})$, squre pyramidal for $\mathrm{ZrO}(\mathrm{II})$ and $\mathrm{VO}(\mathrm{II})$, tetrahedral geometry of $\mathrm{Zn}$ (II), $\mathrm{Cd}(\mathrm{II})$ and $\mathrm{Hg}(\mathrm{II})$.

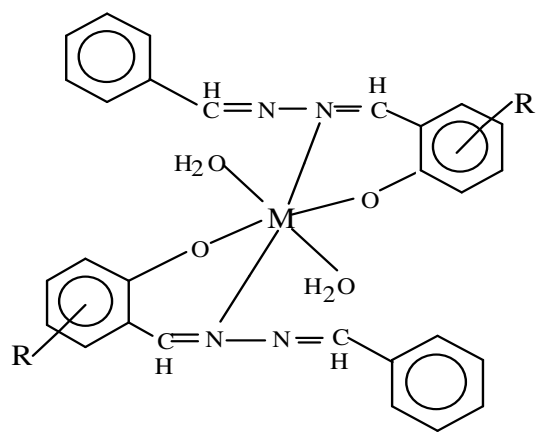

$\mathrm{M}=\mathrm{Mn}(\mathrm{II}), \mathrm{Fe}(\mathrm{III}), \mathrm{Co}(\mathrm{II}), \mathrm{Ni}(\mathrm{II})$ and $\mathrm{Cu}(\mathrm{II})$

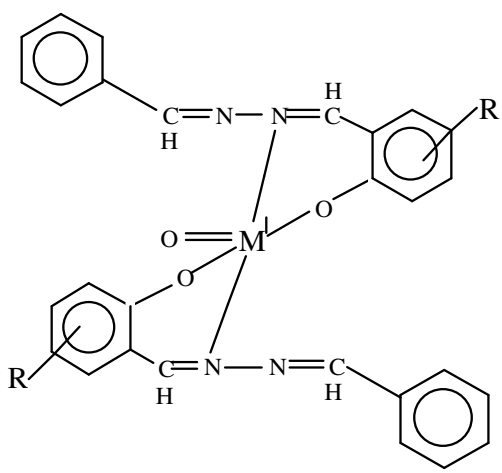

$\mathrm{M}=\mathrm{ZrO}$ (II), $\mathrm{VO}(\mathrm{II}), \mathrm{Zn}(\mathrm{II}), \mathrm{Cd}(\mathrm{II})$ and $\mathrm{Hg}(\mathrm{II})$

\section{References}

1. Albert A Selective Toxicity. The Physico - Chemical basis of Therapy $6^{\text {th }}$ Ed. Chapaman and Hall, London, 1979.

2. Murdock K C, J. Med. Chem. 1982, 25, 505.

3. Kiprinov A I and Verbovskaja T M, Zh. Org. Khim. 1946, 2, 1848.

4. Raybakoya Y A and Bendenyagina N P, Khim, Geterotikl. Soedin. 1966, 20, 287.

5. Bell T W and Papocelis A T, Angew. Chem. 1992, 104, 792

6. Lipper B T, Ed., Chemistry and Biochemistry of a Leading Anticancer Drug; VHCA, Zürich; Wiley-VCH, Weinheim; 1999, 1-563.

7. Reedijk J, Proc. Nat. Acad. Sci. USA, 2003, 100, 3611-3616.

8. Ochocki J, Graczyk J., Pharmazie, 1998, 53, 884-885.

9. Moreno-Luque C. F., Freisinger E., Costisella B, Griesser R., Ochocki J and Lippert B Sigel, H., J. Chem. Soc., Perkin Trans. 2001, 2, 2005-2011.

10. Moreno-Luque C F, Griesser Rochocki J, Sigel H, Zeitschr. Anorgan.Allgem. Chemie 2001, 627, 1882-1887.

11. Kampf G, Lüth M S, Kapinos L E, Müller J, Holy A, Lippert B and Sigel H, J Eur. Chem. 2001,7, 1899-1908. 
12. Sathyanarayana D N, Electronic Absorption Spectroscopy and Related techniques (University Press), India, 2001, 246.

13. Warad U, Satish C D, Kulkarni V H and Chandrashekar S. Bajgur, Indian J. Chem. 2000, 39A, 418-420.

14. Sakurai H, Hiromi W, Tamura H, Yasui H, Rokuji M and Takada, J Inorganica Chimica Acta.1998, 283, 175 - 183.

15. Choudhary Ratan C. K, Choudhary K and. Mishra L. K, J Indian Chem. Soc. 2003, 80, 693.

16. Fenton D E., Advances in Inorganic and Bioorganic mechanisms, Ed, A G Sykes, Academic, London, 1983, 12B, 187.

17. Narayana I, Chim. Acta. 1981,130, 2808.

18. Ullas Shetty N, Revankar V K and Vinayak B. Mahale, Pro. Indian Acd. Sci., (Chem. Sci.) 1997, 109 (1), 7.

19. Sulekh Chandra and Karuna Gupta, Indian J. Chem. 2001, 40A 775.

20. Lakshmi (Mrs.) and Rai R A, J. Inorg. Nucl. Chem, 1984, 42, 450.

21. Satpathy K C, Jal B B and Mishra R, Trans. Met. Chem. 1984, 9, 8.

22. Raman N, Kulandaisamy A and Jeyasubramanian K, J. Indian Chem. 2002, 41A, 942.

23. Koji Abe, Kanako, Matsufuji, Masaaki Ohba and Hisashi Okawa, Inorg. Chem. 2002, 41, 4461-4467.

24. Ketan M, Patel N H, Patel K N, Patel and Patel M N, J. Ind. Chem. Soc., 2000, 17, 19.

25. Campbell M J M. and Grzeskowiak R J. Chem. Soc.1967,396.

26. Biradar N S and Havinale B R, Inorg. Chim. Acta. 1979, 17, 157-160.

27. Bellamy J D L J, IR Spectra of Complex Molecules; John Wiley, New York 1958.

28. Esref Tas, Veli T. Kasumov, Omer Sahin and Mustafa Ozdemir, Trans. Met. Chem. 2002, 27, 442.

29. Unker A, Zarate H and Ishida, J. Phys. Chem. 1996, 100, 13514.

30. Kovacic J E, Spectrochim. Acta.1962, 23A, 183.

31. Raman N, Kulandaisamy A and. Jeyasubramanian K, J. Indian Chem. 2002, 41A, 942.

32. Teyssic P and Charette J J, Spectrochim. Acta. 1963, 19, 1409

33. Ferraro J R, Low Frequency Vibrations of Inorganic and Coordination Compounds; E. L. Mortel, Van Plenum Press, New York, 1971..

34. Hathway. B.t. Struct. Bonding. 1973,14, 60.

35. Choudhary C K, Ratan K, Choudhary and Mishra L K, J Indian Chem. Soc. 2003, 80, 693.

36. Bipin B. Mohapatra and S.K. Saraf. J. Indian. Chem. Soc. 2003, 80, 696.

37. Ramappa PG and Somashekarappa KG, J.Inorg.Biochem. 1994,55,13.

38. Srivastava R S, Inorg.Chim.Act. 1981,56, L65. 


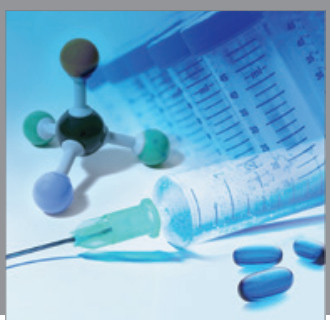

International Journal of

Medicinal Chemistry

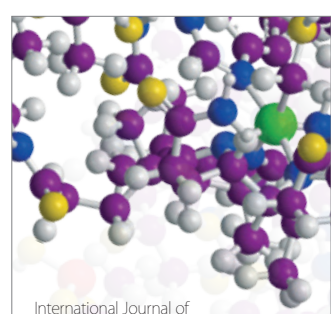

Carbohydrate Chemistry

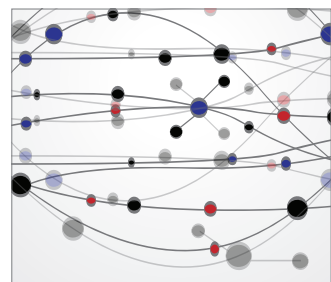

The Scientific World Journal
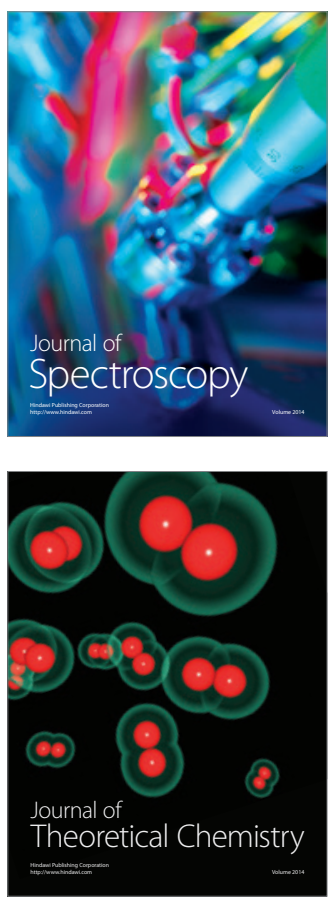
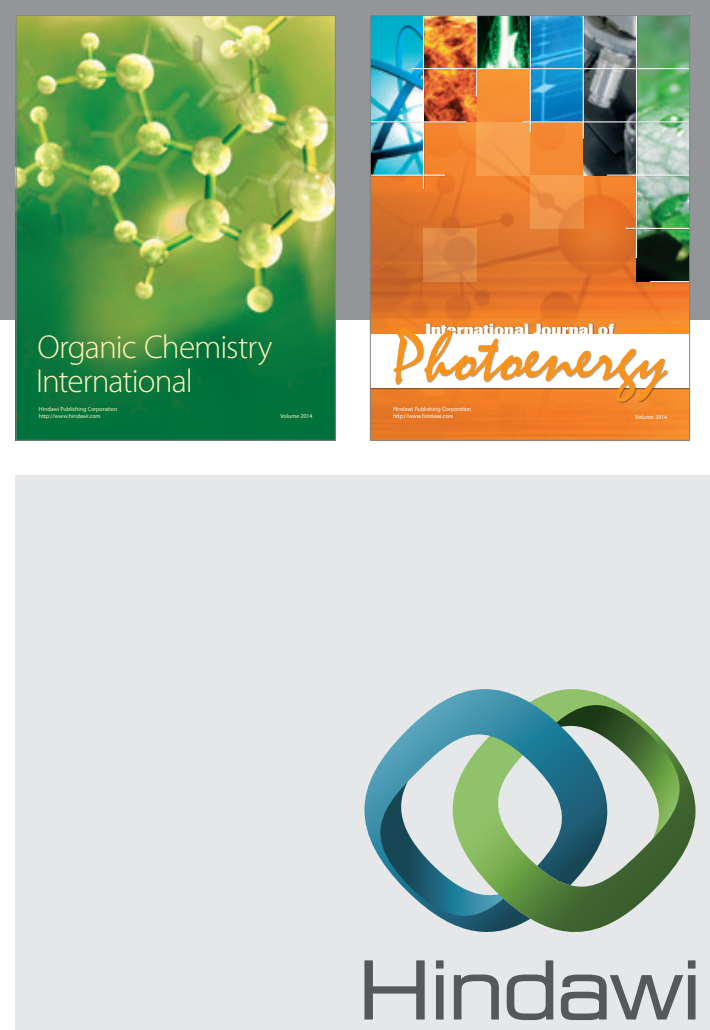

Submit your manuscripts at

http://www.hindawi.com
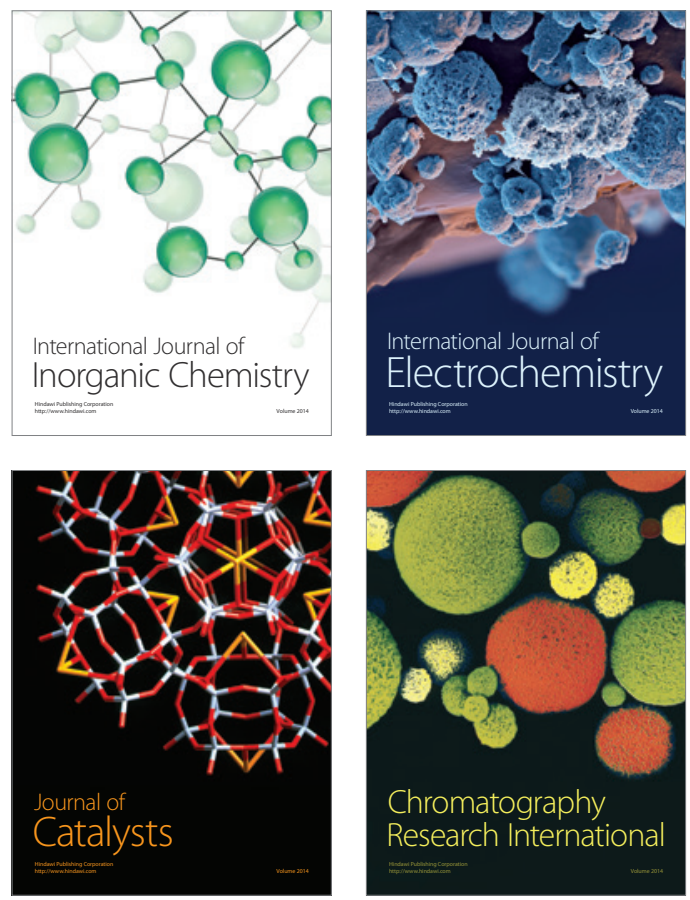
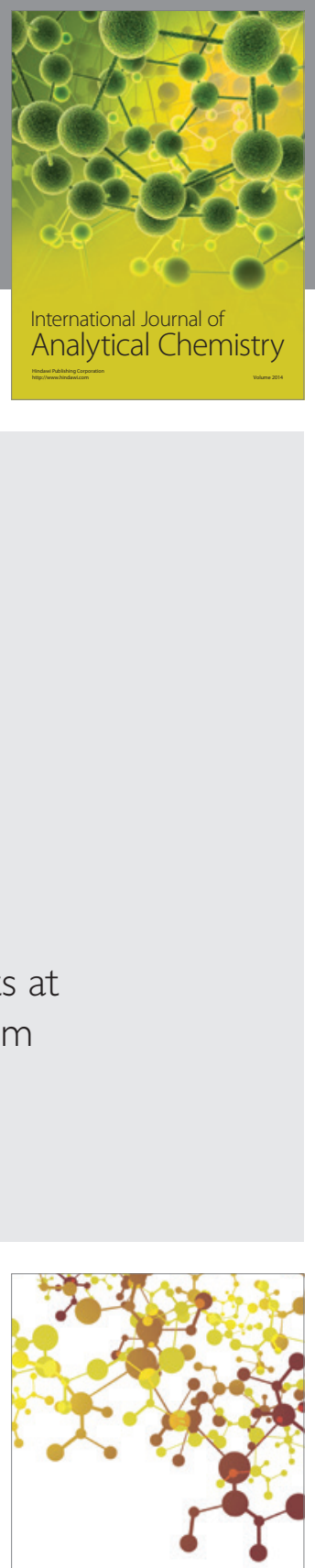

Journal of

Applied Chemistry
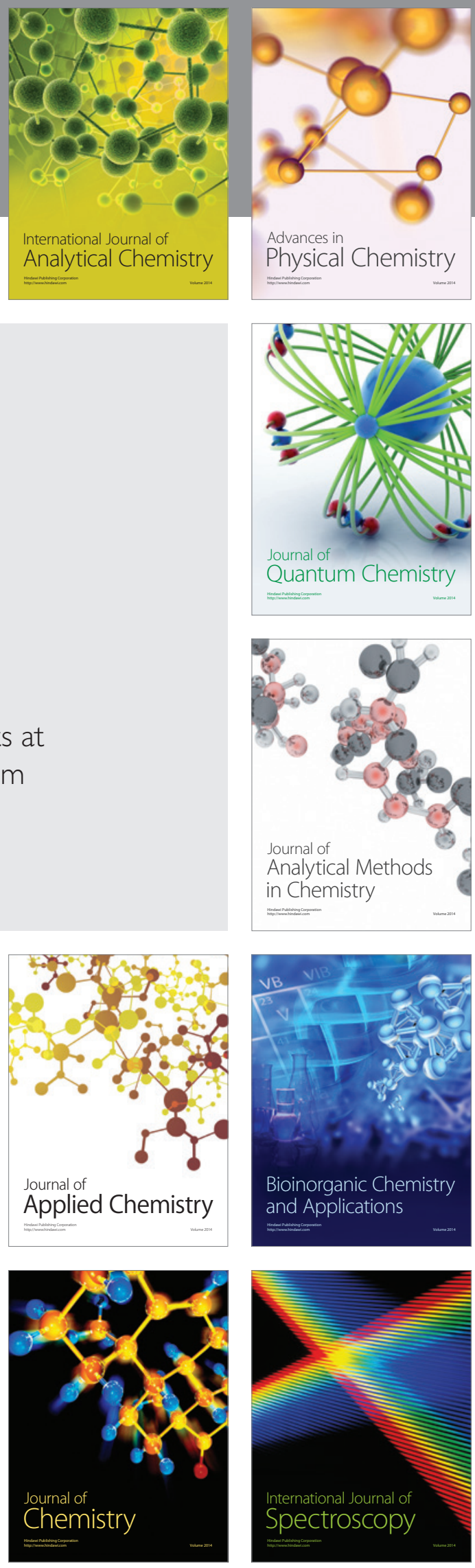